\section{Students knowledge and awareness of oral cancer (study at Senior High School 2 Bau-Bau, Southeast of Sulawesi)}

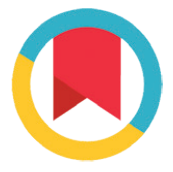

CrossMark

\author{
Anna Mardhiana, Harlina*
}

\section{Abstract}

Objective: Oral cancer is a malignancy which comes from oral mucosal epithelial and other oral parts including from salivary glands (majority are the minor ones) inside the mouth. The aim of this study is to measure the oral cancer qualitatively and spread knowledge and awareness among the students at SMAN 2 Bau-Bau.

Material and Methods: The type of this research is observationaldescriptive study, with cross-sectional study as the research design. This research was carried out at SMAN 2 Bau-Bau. Bau-Bau, Southeast Sulawesi from February to March 2015. The sampling method applied was cluster random sampling.

Results: this research was carried out to 155 students of SMAN 2 Bau-Bau which consisted of 102 female students and 53 male students. There were about $79.3 \%$ samples who have never heard about it yet. Samples knowledge about age that have a bigger risk to get oral cancer was 18 samples (11.6\%) chosen was $0-18$ years old, 65 samples (41.9\%) chosen was 19-25 years old, 40 samples (25.8\%) chosen was $26-44$ years old and about 32 samples (20.6\%) chosen was more than 44 years old. There was no sample chose that we can decrease the possibilities to get oral cancer by having a good life style. There were about 108 samples (69.6\%) who had never done all of them (smoking, drinking alcohol and piercing their lips or tongue).

Conclusion: The reason behind unknown action is the lack of information and socialization about oral cancer.
Department of Oral Medicine, Faculty of Dentistry, Hasanuddin University, Makassar, Indonesia
*Correspondence to: Harlina, Department of Oral Medicine, Faculty of Dentistry, Hasanuddin University, Makassar, Indonesia harlinailmar@yahoo.com

Received: 01 April 2016

Revised: 25 April 2016

Accepted: 26 April 2016

Available Online: 30 April 2016

Keywords: Knowledge, Awareness, Students, Oral cancer

Cite This Article: Mardhiana A, Harlina. 2016. Students knowledge and awareness of oral cancer (study at Senior High School 2 Baubau, Southeast of Sulawesi). Journal of Dentomaxillofacial Science 1(1): 45-48. D01: 10.15562/jdmfs.v1i1.24

\section{Introduction}

Oral cancer is a malignancy which comes from the epithelial oral mucosa and another oral's organ and also from salivary glands (especially the minor one) inside the mouth. ${ }^{1}$ The development of oral cancer is so fast. A few of oral cancer can be diagnosed at the late level with high die rate. Only half of diagnostic case will survive more than 5 years, but if we can know it at the early stage, about $80-90 \%$ can live. ${ }^{2}$ Early detection is one of the most important part of a success treatment and for the survival of the patient especially inside the mouth. However, early detection of the fierceness from the oral cancer is not easy, it can be proved from the low rate of the healing, as reported that $50 \%$ diagnosed patients have already reached regional metastasis or even to further stage. Early detection of oral cancer which is asymptomatic will increase quality of life of the patient and minimize hard treatment. ${ }^{2}$

Actually, premalignant condition and early malignant cannot be identified by visual examination because many things that cannot be seen and cannot be ignore, even by the professional who has a lot of experience. Clinical appearance of premalignant and oral malignance is asymptomatic, so it makes the condition hard to be detected. There are varied clinical appearances from oral cancer and usually do not seem so dangerous like ulceration, induration, nodule, bleeding and enlargement of lymphoid glandule in the neck. ${ }^{2}$

Manifestation of oral cancer that is usually seen is leukoplakia. A majority of oral cancer is due to leukoplakia. About 16-23\% of leukoplakia can change into oral squamous cell carcinoma, even it has been reported that there is a relationship between oral squamous cell carcinoma and leukoplakia. $^{2}$

Biopsy result shows that about $43 \%$ of leukoplakia in the mouth has premalignant sign which is known by dysplastic cell or shoreless carcinoma in the epithelium (carcinoma in situ), even the carcinoma could spread into the layer above epithelium or invasive carcinoma which is a squamous cell carcinoma. $^{2}$

Early detection can make a good prognoses. ${ }^{2}$ One of the causes of delayed diagnostic in oral cancer is due to inadequate knowledge and awareness from the society about the danger of oral cancer and it makes them not to approach the medical service ${ }^{3}$

\section{Material and Methods}

The type of this research is observationaldescriptive study, with cross-sectional study as the 
research design. This research was carried out at SMAN 2 Bau-Bau, Bau-Bau, Southeast Sulawesi from February to March 2015. The sample was the students of SMAN 2 Bau-Bau. The sampling method applied was cluster random sampling and the total samples was $20 \%$ from all of the students (155 students)

\section{Results}

Figure 1 this research was carried out to 155 students of SMAN 2 Bau-Bau which consisted of 102 female students and 53 male students.

Sample's knowledge about early detection of oral cancer are still low, total samples who have ever heard about early detection of oral cancer was only 32 samples and total samples who have never heard about early detection was 132 samples. In other words, there were about $79.3 \%$ samples who have never heard about it yet.

Samples knowledge in term of dominant sex who had a high risk to have oral cancer was 83 samples (53.5\%) of the chosen male and female had the

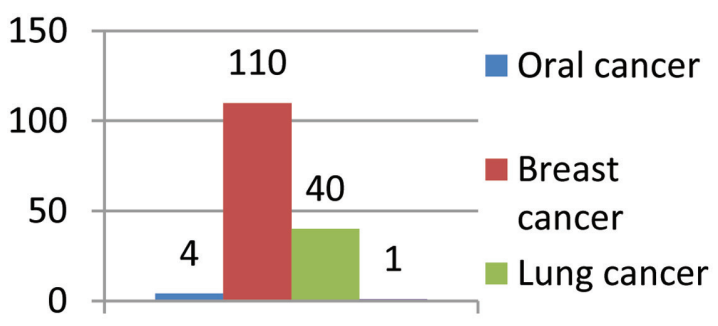

Figure 1 Well-known cancer

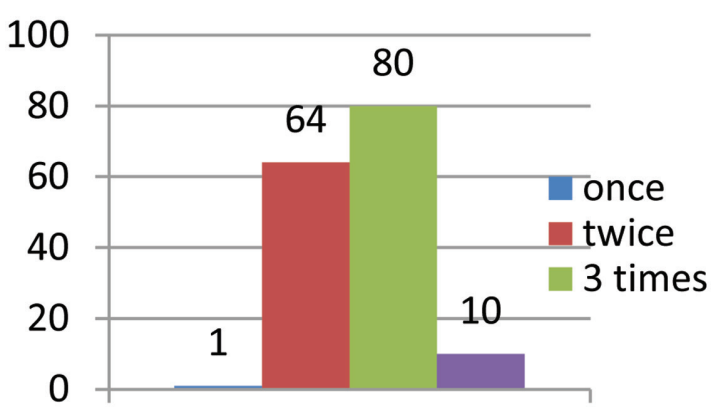

Figure 3 Frequency of brushing teeth

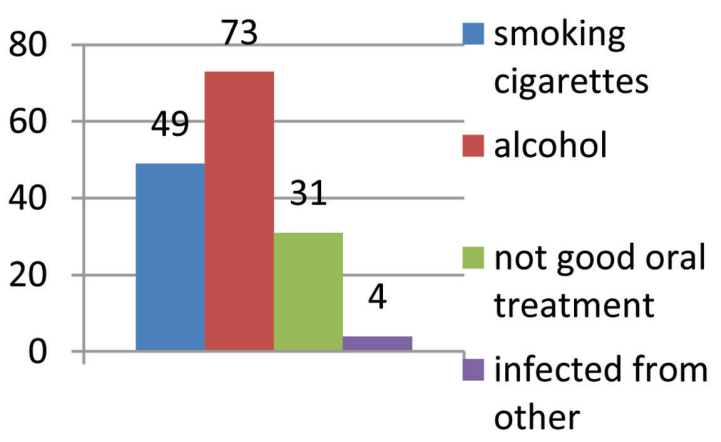

Figure 5 The cause of oral cancer same risk to have oral cancer. 64 samples $(41.3 \%)$ of the chosen male to had a higher risk to have oral cancer and about 8 samples (5.1\%) of the chosen female who had a bigger risk to have oral cancer.

Samples knowledge about oral cancer among 10 cancers which occurs the most was still low. As more than half from the samples doesn't know about it. About 109 samples (70.3\%) did not know and only 46 samples (29.7\%) knew it.

Samples knowledge about age that have a bigger risk to get oral cancer was 18 samples (11.6\%) chosen was 0 -18 years old, 65 samples $(41.9 \%)$ chosen was 19-25 years old, 40 samples $(25.8 \%)$ chosen was 26-44 years old and about 32 samples (20.6\%) chosen was more than 44 years old.

Samples knowledge about the belief that if we can decrease the possibilities to get oral cancer by having a good lifestyle was 145 samples (93.5\%) so 10 samples $(6.5 \%)$ did not know about it and there was no sample chose that we can decrease the possibilities to get oral cancer by having a good life style.

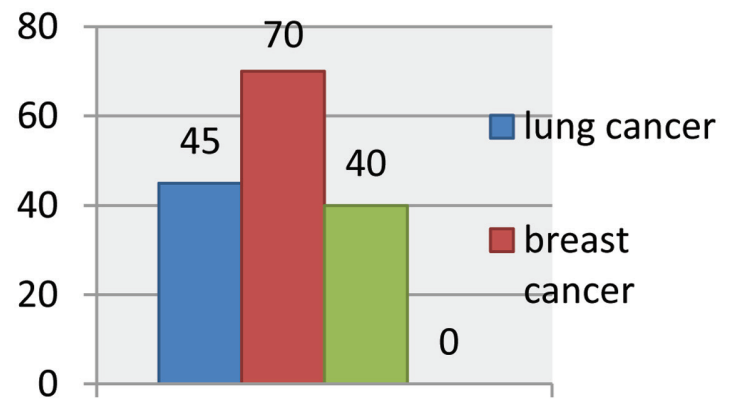

Figure 2 The easiest detectable cancer

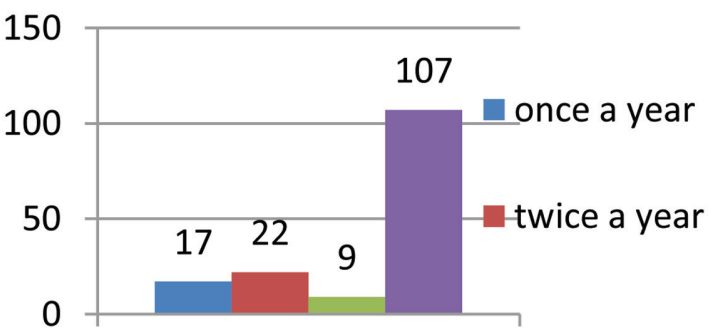

Figure 4 Frequency of visiting dentist

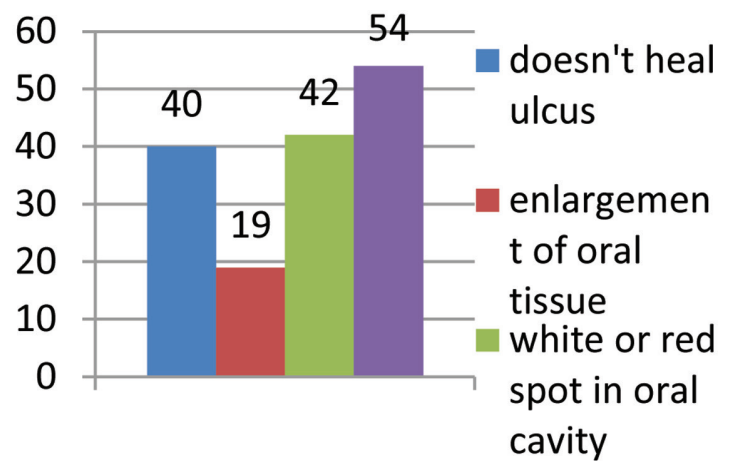

Figure 6 Samples knowledge about the signs of oral cancer 
Samples habits related to the awareness of oral cancer and a good lifestyle were 16 samples (10.3\%), that had smoking habit were 8 samples $(5.2 \%)$ and had ever scrapped their teeth 5 samples (3.2\%), used fix orthodontic not from their dentist 5 samples (3.2\%), pierced their lips or tongue 5 samples (3.2\%), smoked and consumed alcohol 3 samples (1.9\%). Finally, there were about 108 samples (69.6\%) who had never done all of them (smoking, drinking alcohol and piercing their lips or tongue)

\section{Discussion}

Oral cancer awareness and knowledge on oral cancer of SMAN 2 Bau-Bau students are still low. In this research, we found that $2.6 \%$ chosen samples with oral cancer as the well-known cancer, followed by breast cancer (70.9\%), lung cancer $(25.8 \%)$ and prostate cancer $(0.7 \%)$. Samples believed that drinking alcohol is the main cause of oral cancer, (31.6\%) chose smoking cigarettes to be one factor contributed to oral cancer and the rest chose bad treatment as the cause of oral as well as infected by other patients.

Research done by Palensia et al. ${ }^{3}$ reported that society realizes smoking cigarettes as the main cause of dentomaxillofacial cancer. In term of student's knowledge about the sign of oral cancer's sign, there were about 54 samples (34.8\%) did not know the sign, 42 samples (27.1\%) chose enlargement of oral tissue as the sign of oral cancer and 19 samples (12.2\%) chose red or white spot as the sign of oral cancer. The majority of students agreed that if they do a good lifestyle then they can decrease the possibilities of having oral cancer. Research in Portugal also reported that only ulcers that never healed as the sign of oral cancer. ${ }^{3}$ A situation like this happened in Bau-Bau, the family of the patient said that the early sign of oral cancer that their family gets was ulcers which never healed, even when they already gave it medical attention. They also reported that their family who got oral cancer did not have a healthy lifestyle, in which they love to eat fast food and were also being active smokers.

Sample's knowledge about early detection of oral cancer was still low, total samples who have heard about early detection of oral cancer were only 32 samples and total samples who have never heard about early detection were 132 sample, there were about $79.3 \%$ who had never heard about oral cancer.

The awareness of students in SMAN 2 Bau-Bau on oral cancer was proved by keeping their mouth clean, even a number of students routinely to visit dentist. It shows that there is a relationship between the oral cancer awareness and knowledge. If the society knows the sign, causes and effect of oral cancer, then their awareness about it also will increase.

\section{Conclusion}

Oral cancer awareness and knowledge among the students in SMAN 2 Bau-Bau is still low because they have inadequate information among the students and there are less socialization about oral cancer.

\section{Conflict of Interest}

The authors report no conflict of interest.

\section{References}

1. Messadi DV, Wilder-Smith P, Wolinsky L. Improving oral cancer survival: the role of dental providers. J Calif Dent Assoc 2009;37: 789-798.

2. Langevin SC, Michaud DS, Elliot M, et al. Regular dental visits are associated with earlier stage at diagnosis for oral and pharyngeal cancer. Cancer Causes Control 2012;23: 1281-1829.

3. Monteiro LS, Salazar F, Pachecho J, et al. Oral cancer awareness and knowledge in the city of valongo, portugal. Int J Dent 2012.

4. Sudiono J. Pemeriksaan patologi untuk diagnosis neoplasma mulut. Jakarta: EGC; 2008. p. 6, 23-25, 29-30, 51-52.

5. Patel JB, Shah FD, Shuklah SN, et al. Role of nitric oxide and antioxidant enzyme in the pathogenesis of oral cancer. J Cancer Res Ther 2009;5: 247-253.

6. Manuaba TW. Panduan penatalaksanaan kanker solid peraboi 2010. Jakarta: Sagung Seto; 2010. p. 98-100, 104-108.

7. Awojobi O, Scott SE, Newton T. Patients' perceptions of oral cancer screening in dental practice: a cross-sectional study. BMC Oral Health 2012: 12:55.

8. Pederson GW. Buku ajar praktis bedah mulut (oral surgery). In LilianYuwono. Editor. Jakarta: EGC; 2013. p. 158-159.

9. Jang JY, Kim MJ, Ryu G, et al. Original article: prediction of lymph node metastasis by tumor dimension versus tumor biological properties in head and neck squamous cell carcinomas. Cancer Research and Treatment 2014.

10. Chattopadhyay A. Oral health epidemiology: principle and practice. USA: Jones and Bartlett Publishers 2011: 271-289.

11. Squier C. Introduction: Tobacco. human disease, and the role of the dental profession. J Dent Education 2001: 303-304.

12. Handayani N. Terjadinya leukoplakia akibat pemakaian tembakau (leukoplakia on tobacco user). Journal PDGI 2007;57: 11-14.

13. Messadi DV. Diagnostic aids for detection of oral precancerous conditions. Int J Oral Sci 2013;5: 59-65.

14. Michi P, Pazdera J, Prochazka M, et al. Human papillomavirus in the etiology of head and neck carcinomas. Biomed Pap Med Fac Univ Palacky Olomouc Czech Repub 2010;154: 9-12.

15. Galle F, Collela G, Onofrio DV, et al. Candida spp. In oral cancer and oral precancerous lesions. New Microbiologica 2013;36: 283-288

16. Nersesyan A, Muradyan R, Kundi M, et al. Impact of smoking on the frequencies of micronuclei and other nuclear abnormalities in exfoliated oral cells: a comparative study with different cigarette types. Mutagenesis 2011;26: 295-301.

17. Sujatha D, Hebbar PB, Pai A. Prevalence and correlation of oral lesions among tobacco smokers, tobacco chewers, areca nut and alcohol users. Asian Pacifis J Cancer Prev 2012;13: 1633-1637.

18. Yardimci G, Kutlubay Z, Engin B, et al. Precancerous lesions of oral mucosa. World J Clinical Cases 2014;2: 866-872. 
19. McCord C, Xu J, Xu W, et al. Association of human papilloma virus with atypical and malignant oral papillary lesions (Original article). Oral Sug Oral Med Oral Pathol Oral Radiol 2014;117: 722-732.

20. Ara SA, Arora V, Zakaullah S, et al. Correlation of habits and clinical finding with histopathological diagnosis of oral submucosal fibrosis patients. Asian Pac J Cancer Prev 2013;14: 7075-7080.

21. Silverman S, Eversole LR. Essentials of oral medicine. Canada: BC Decker Inc; 2002. p. 192-193, 211.

22. Anonim. Oral Cancer. US. Department of Health and Human Services. National Institute of Dental and Craniofacial Research 2008: 5008-5032.

23. Jayaprakash, Vijayvel. Autofluorescence-guided surveillance for oral cancer. Cancer Prevention Research 2009;2: 966-974.

24. Speight PM. The cost effectiveness of screening for oral cancer in primary care. Health Technology Assesment. 2006;10: 141-146.

25. Butterworth, Mike. Opportunistic oral cancer screening. BDA: Occasional Paper; 2000. p. 1-34.
26. Sunaryo. Psikologiuntukkeperawatan. Jakarta: EGC; 2004. p. 25-27, 77-79.

27. RadiLaega. SMAN 2 Bau-Bau. 14 Februari 2014. http:// smanegeri2baus.blogspot.com/. Accessed: 5 April 2015.

28. Profil SMAN 2 Baubau. http://40402768.siap-sekolah. com/sekolah-profil/. Accessed: 5 April 2015.

29. Al-Maweri SA, Abbas A, Tarakji B, et al. Knowledge and opinions regarding oral cancer among Yemeni dental students. Asian Pacific J Cancer Prevention 2015: 1765-1770.

30. Shaila M, Shetty P, Decruz AM, et al. The self-reported knowledge, attitude and the practices regarding the early detection of oral cancer and precancerous lesions among the practicing dentists of Dakshina Kannada-A pilot study. J Clinical Diagnostic Research 2013: 1491-1494.

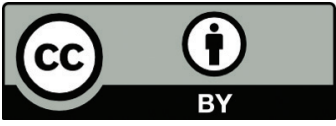

This work is licensed under a Creative Commons Attribution 